\title{
Original Research \\ Detoxification of Electroplating Sludge by Bioleaching: Process and Kinetic Aspects
}

\author{
Sundramurthy Venkatesa Prabhu ${ }^{1 *}$, Rajoo Baskar ${ }^{2}$ \\ 'Department of Biotechnology, Centre for Research, K.S. Rangasamy College of Technology, Tiruchengode 637215, India \\ ${ }^{2}$ Department of Chemical Engineering, Centre for Research, Kongu Engineering College, Erode 638052, India
}

Received: 24 June 2014

Accepted: 23 September 2014

\begin{abstract}
The presence of significant amounts of heavy metals in industrial sludge poses a severe threat to the environment and human health. In this study, bioleaching of heavy metals from electroplating industrial sludge was investigated using indigenous Acidithiobacillus ferrooxidans as the bacterial agent. The effect of sludge loading on the efficiency of heavy metal removal by bioleaching was studied. The efficiency of bioleaching was assessed based on media acidification, oxidation-reduction potential, and concentration of heavy metals in the aqueous solution. Experimental results showed that the sludge loading had great impact on the bioleaching process. At sludge loading of $1 \%(\mathrm{w} / \mathrm{v})$, maximum removal of $96.31 \%$ and $84.4 \%$ was achieved for the heavy metals $\mathrm{Zn}$ and $\mathrm{Ni}$, respectively. Bioleaching data were subjected to first-order-based kinetic studies for rate constant and further shrinking core model analysis was applied. It was found that the rate constants for $\mathrm{Zn}$ and Ni bioleaching were maximum at the treatment with lower sludge loading. The kinetic analysis using the shrinking core model revealed that chemical reaction step controls the overall rate of the bioleaching process. Such a kinetic study will be helpful in designing the sludge detoxification process by bioleaching.
\end{abstract}

Keywords: electroplating sludge, A. ferrooxidans, bioleaching, rate kinetics, shrinking core model

\section{Introduction}

Electroplating is the application of metal coating to a metallic or other conducting surface by an electrochemical process. Articles are electroplated to alter their appearance, provide protective coating, give them specific mechanical properties, and attain special surface properties [1]. The electroplating process generates huge quantities of wet sludge containing heavy metals as pollutants at the wastewater treatment unit $[2,3]$. The major heavy metals present in the sludge are cadmium, chromium, lead, copper, zinc, and nickel [4, 5]. Electroplating sludge is categorized as hazardous waste by statutory authorities and is processed for metal recovery by suitable technologies before disposal [6-8]. Improper disposal of industrial sludge may contami-

*e-mail: haiitsvp@yahoo.co.in nate surface water and groundwater with heavy metals and put the surrounding environment under risk and spoil human health [9-11]. Hence, electroplating sludge should be treated for removal of the heavy metals before considering any disposal methodology.

Currently, various chemical and biological methods are available to detoxify industrial sludge, and selection of a suitable process depends on both technical and economic feasibility [12]. Owing to the consumption of a large amount of inorganic acids, the chemical leaching process is often more expensive than the biological process, and thus paves the way for developing the biological leaching (bioleaching) process $[13,14]$. In the bioleaching process, the filamentous fungi and lithotrophic bacteria from Acidithiobacillus genus are used as biological agents [15, 16]. In comparison, the efficiency of removing heavy metals is found to be less for fungal bioleaching than for bacte- 
rial bioleaching [17]. Bioleaching through bacterial activity is carried out usually by either direct or indirect mechanism [18]. In direct mechanism, non-soluble metal sulfides are oxidized into water-soluble metal sulfates (Eq. 1) by chemolithotrophic bacteria such as Acidithiobacillus ferrooxidans, A. thiooxidans, A. caldus, Sulfobacillus acidophilus, and Acidiphilium acidophilum [19, 20]. In indirect mechanism, elemental sulfur $\left(\mathrm{S}^{\circ}\right)$, is oxidized first to sulfuric acid (Eq. 2) by sulfur-oxidizing bacteria and then dissolution of metals by sulfuric acid takes place (Eq. 3) [21]:

$$
\begin{array}{lrr}
\mathrm{MS}+2 \mathrm{O}_{2} & \text { Thiobacilli bacteria } & \mathrm{MSO}_{4} \\
\mathrm{~S}^{\mathrm{o}}+\mathrm{H}_{2} \mathrm{O}+1.5 \mathrm{O}_{2} & \text { Thiobacilli bacteria } & \mathrm{H}_{2} \mathrm{SO}_{4} \\
\mathrm{H}_{2} \mathrm{SO}_{4}+\text { Sludge-M } & \text { Sludge- } 2 \mathrm{H}+\mathrm{MSO}_{4}
\end{array}
$$

...where $\mathrm{M}$ is bivalent metal.

The indirect mechanism is often considered for the removal of heavy metals from sludge using sulfur-oxidizing bacteria. Though numerous works have been published on different parameters of bioleaching $[22,23]$ on sludge, only a few have looked into the bioleaching kinetics [24, 25]. The kinetics for rate and determination of rate-controlling step are very important in thorough understanding of the bioleaching process [26]. It owns a vital part to represent the process mathematically. Thus, it is necessary to investigate and analyze the kinetics of the bioleaching process in the direction of designing the sludge detoxification process. The objective of this work was to study the effect of sludge loading (SL) on bioleaching of heavy metals ( $\mathrm{Zn}$ and $\mathrm{Ni}$ ) from electroplating industrial sludge and to study the kinetics for rate and rate-controlling step of the bioleaching process using isolated $A$. ferrooxidans.

\section{Materials and Methods}

\section{Sludge Collection and Characterization}

For this study, heavy metal-bearing sludge was collected from an effluent treatment plant of the industrial electroplating sector (Chennai, India). The top surface of the sludge bed has more waterlogged phase with presence of chemically oxidized water-soluble compounds that cannot provide original property of the sludge. So the sludge sample was collected at a depth of 2-5 cm from the surface of the sludge bed because there will not be a remarkable difference in the physiochemical properties of the sludge sample at this depth to bottom surface. It can be considered as representative of generated sludge. The collected sample was stored using a polyethylene bag at $4^{\circ} \mathrm{C}$ before use for experiments to avoid change in its properties. It was airdried at room temperature overnight. Total metal concentration in the sludge was determined after acid digestion with a mixture of concentrated $\mathrm{HNO}_{3}, \mathrm{HClO}_{4}$, and $\mathrm{HF}$ [27]. The concentration of the dissolved metals in the sludge was determined after membrane filtration $(0.45 \mu \mathrm{m}$ pore size $)$, and analysis was conducted using an atomic absorption spectrometer (AA200 model; PerkinElmer; USA). Ionic activity and electrical conductivity of the extract collected from dry sludge to water in the ratio of 10:25 were measured using a calibrated $\mathrm{pH}$ meter (Eutech Instruments, Singapore) and a conductivity meter (Elico, India) [28]. The presence of organic matter in the sludge was determined using Walkley-Black method with standard $1 \mathrm{~N}$ $\mathrm{K}_{2} \mathrm{Cr}_{2} \mathrm{O}_{7}$ and Ferroin indicator. Total nitrogen content was estimated using micro-Kjeldahl distillation apparatus. Available phosphorus in the sludge was determined using the micro-vanadate-molybdate method after extraction with $0.5 \mathrm{M}$ sodium bicarbonate. Calcium, magnesium, and potassium were determined using the flame photometer (CL378 model; Elico; India) after ammonium acetate extraction [29]. Soluble sulfate was estimated using a UVvisible spectrophotometer (U2900 model; Hitachi; Japan) after precipitation as barium sulfate according to the American Public Health Association (APHA) standard.

\section{Microorganism and Sludge Acclimatization}

The sulfur-oxidizing bacteria $A$. ferrooxidans were isolated from water samples collected from acid mine drainage in Chitradurga copper mine (Karnataka, India). They were screened using elemental sulfur as the key nutrient in the medium [30] with the following chemical composition: $\mathrm{S}^{\mathrm{o}}$ (10 g. $\left.{ }^{-1}\right), \mathrm{MgSO}_{4} \cdot 7 \mathrm{H}_{2} \mathrm{O}\left(0.5 \mathrm{~g} \cdot \mathrm{l}^{-1}\right),\left(\mathrm{NH}_{4}\right)_{2} \mathrm{SO}_{4}\left(3 \mathrm{~g} \cdot \mathrm{l}^{-1}\right)$, $\mathrm{K}_{2} \mathrm{HPO}_{4}\left(0.5 \mathrm{~g} \cdot \mathrm{l}^{-1}\right), \mathrm{Ca}\left(\mathrm{CO}_{3}\right)_{2}\left(0.01 \mathrm{~g} \cdot \mathrm{l}^{-1}\right)$, and $\mathrm{KCl}\left(0.1 \mathrm{~g} \cdot \mathrm{l}^{-1}\right)$. A brief literature survey showed that the optimal $\mathrm{pH}$ value of $A$. ferrooxidans is between 2 and 4 [31]. So the media $\mathrm{pH}$ was initialized to 3 using sulfuric acid for stimulating bacterial growth. The isolate was subcultured several times in the same medium for further activation. To acclimatize the culture to sludge, we added $0.25 \%(\mathrm{w} / \mathrm{v})$ dry sludge as a supplement to the subculture medium at room temperature $\left(28^{\circ} \mathrm{C}\right)$. The flasks were shaken at $150 \mathrm{rpm}$ in a horizontal rotary shaker. The decrease in $\mathrm{pH}$ was monitored until it stagnated during growth. Two more subcultures were carried out with $0.25 \%(\mathrm{w} / \mathrm{v})$ sludge as a supplement. A portion of this culture was further cultivated in the medium with $0.5 \%(\mathrm{w} / \mathrm{v})$ dry sludge under similar conditions $\left(28^{\circ} \mathrm{C}\right.$ and $150 \mathrm{rpm}$ ) to produce mild-acclimatized culture. A portion of this mild-acclimatized culture was further acclimatized with $0.75 \%(\mathrm{w} / \mathrm{v})$ and $1 \%(\mathrm{w} / \mathrm{v})$ dry sludge to produce required acclimatized culture to sludge. The sludge-acclimatized culture was used as inoculum for bioleaching experiments.

\section{Bioleaching Experiments}

The bioleaching studies were conducted in $250 \mathrm{ml}$ Erlenmeyer flasks, each containing $90 \mathrm{ml}$ medium, $10 \mathrm{ml}$ inoculum, and predetermined amounts of SL. In the flask, SLs were $1.0 \%, 2.0 \%, 3.0 \%, 4.0 \%$, and $5.0 \%(\mathrm{w} / \mathrm{v})$. All flasks were incubated in a rotary shaker at $28^{\circ} \mathrm{C}$ and 150 rpm. Control experiments without the addition of inoculum were also maintained in $1 \% \mathrm{SL}$ for comparison. To the medium, $5 \%(\mathrm{v} / \mathrm{v})$ alcoholic thymol solution $(1 \%(\mathrm{w} / \mathrm{v})$ thymol crystal in alcohol) was added as bacterial germicide in control experiments. During bioleaching studies, $\mathrm{pH}$ and 
oxidation-reduction potential (ORP) were monitored using a calibrated $\mathrm{pH}$ meter and $\mathrm{Pt}-\mathrm{Ag} / \mathrm{AgCl}$ electrode, respectively, at $24 \mathrm{~h}$ intervals. At every $48 \mathrm{~h}$ interval, $5 \mathrm{ml} \mathrm{sam}$ ples were periodically withdrawn and centrifuged at 3,000 $\mathrm{rpm}$ for $20 \mathrm{~min}$. The supernatant was filtered using Whatman filter paper and preserved at $4^{\circ} \mathrm{C}$ before determining the concentration of leached $\mathrm{Zn}$ and $\mathrm{Ni}$ by atomic absorption spectrometry. A fresh nutrient solution without elemental sulfur was added to compensate for the media loss due to sample collection and evaporation. Metal bioleaching efficiency, denoted by $(\%)$, was calculated using the following equation:

$$
\eta \%=\left(\frac{M_{0}-M_{\text {soln }}}{M_{\mathrm{T}}}\right) \times 100
$$

...where $M_{0}$ and $M_{\text {soln }}$ are the solubilized metal concentration in aqueous phase at zero time and time $t$, respectively. $M_{\mathrm{T}}$ is the total metal concentration in the primary sludge. All experiments were carried out in triplicate and mean values with standard deviation of parameters being expressed as results.

\section{Kinetic Studies for Rate Constant and Rate-Controlling Step}

Rate of bio-solubilization of heavy metal by bioleaching can be described by the following empirical equation [32]:

$$
\frac{\mathrm{d} C_{\mathrm{M}}}{\mathrm{d} t}=k_{\mathrm{m}}\left(C_{\mathrm{M}, 0}-C_{\mathrm{M}, t}\right)
$$

Integrating the above first-order equation between limits of initial and final values of metal concentration and time (at $t=0, C_{\mathrm{M}}=0$ and at $t=t \mathrm{~h}, C_{\mathrm{M}}=C_{\mathrm{M}, t}$ ) results in the following equation:

$$
\ln \left(\frac{C_{\mathrm{M}, 0}}{C_{\mathrm{M}, 0}-C_{\mathrm{M}, t}}\right)=k_{\mathrm{m}} t
$$

...where $C_{\mathrm{M}, 0}$ and $C_{\mathrm{M}, t}$ are the total concentrations of metal available in the primary sludge and concentrations of metal in the aqueous phase of leached solution at time $t$ during the process. $k_{m}$ is the bioleaching rate constant and is obtained from the slope of the plot, $\ln \left(C_{\mathrm{M}, 0} /\left(C_{\mathrm{M}, 0}-C_{\mathrm{M}, t}\right)\right) v s$ time. The analysis of sludge bioleaching mechanism is of immense importance for designing and further application of the process. Thus, the rate-controlling step of the reaction has been analyzed using the shrinking core model (SCM) of fluid-particle reaction kinetics [33]. According to the SCM, steps involved to control the overall reaction rate and its respective mathematical models in terms of conversion and leaching time are given in Table 1, where $X_{\mathrm{M}}$ is the fraction of leached metal in aqueous phase and kobs the observed kinetic constant applicable to the respective model. On the basis of the regression analysis from the plots $\left[1+2\left(1-X_{\mathrm{M}}\right)\right.$ $\left.3\left(1-X_{\mathrm{M}}\right)^{2 / 3}\right]$ vs time, $\left[1-\left(1-X_{\mathrm{M}}\right)^{1 / 3}\right]$ vs time, and $\left[X_{\mathrm{M}}\right]$ vs time, the rate-controlling step was identified for the respective metal bioleaching [34].
Table 1. Mathematical models of rate-controlling steps.

\begin{tabular}{|l|c|}
\hline \multicolumn{1}{|c|}{ Controlling step } & Mathematical model \\
\hline Diffusion through the ash layer & $1+2\left(1-\mathrm{X}_{\mathrm{M}}\right)-3\left(1-\mathrm{X}_{\mathrm{M}}\right)^{2 / 3}=k_{\text {obs }} \mathrm{t}$ \\
\hline Chemical reaction & $1-\left(1-\mathrm{X}_{\mathrm{M}}\right)^{1 / 3}=k_{o b s} \mathrm{t}$ \\
\hline Diffusion through liquid film & $\mathrm{X}_{\mathrm{M}}=k_{\text {obs }} \mathrm{t}$ \\
\hline
\end{tabular}

Table 2. Physico-chemical properties of sludge sample.

\begin{tabular}{|c|c|c|}
\hline Sl. No. & Selected parameters & Composition \\
\hline 1 & $\mathrm{pH}$ & $8.2 \pm 0.24$ \\
\hline 2 & Conductivity & $3.7 \mathrm{cmol}$ \\
\hline 3 & Total nitrogen & $3978 \pm 67 \mathrm{mg} / \mathrm{kg}$ \\
\hline 4 & Total available phosphorus & $2452 \pm 46 \mathrm{mg} / \mathrm{kg}$ \\
\hline 5 & Sulfate & $520 \pm 58 \mathrm{mg} / \mathrm{kg}$ \\
\hline 6 & Organic mater & $4.1 \pm 0.11 \%$ \\
\hline 7 & Calcium & $21,520 \pm 176 \mathrm{mg} / \mathrm{kg}$ \\
\hline 8 & Magnesium & $9560 \pm 243 \mathrm{mg} / \mathrm{kg}$ \\
\hline 9 & Potassium & $284 \pm 36 \mathrm{mg} / \mathrm{kg}$ \\
\hline 12 & Zinc & $42,180 \pm 685 \mathrm{mg} / \mathrm{kg}$ \\
\hline 13 & Nickel & $20,160 \pm 430 \mathrm{mg} / \mathrm{kg}$ \\
\hline
\end{tabular}

\pm indicates the standard deviation of data represent mean value of five samples.

\section{Results and Discussion}

\section{Characteristics of Microorganism and Sludge}

The bacterium $A$. ferrooxidans is gram-negative, nonsporulating rod (0.5-0.6 m wide and 1.0-2.0 m long with rounded ends) capable of oxidizing iron and sulfur and occurring singly or in pairs. All the mentioned characteristics were observed during the isolation of the strain. The scanning electron microscopy image of the isolate is given in Fig. 1. Table 2 lists the characteristics of electroplating the industrial sludge sample on a dry basis. The characterization study of the sludge revealed its alkaline nature. The sludge was rich in nitrogen $\left(3,978 \mathrm{mg} \cdot \mathrm{kg}^{-1}\right)$ and phosphorus $\left(2,452 \mathrm{mg} \cdot \mathrm{kg}^{-1}\right)$, and also contained moderate levels of potassium $\left(284 \mathrm{mg} \cdot \mathrm{kg}^{-1}\right)$ that could be used by $A$. ferrooxidans culture during bioleaching. Calcium and magnesium concentrations were 21,520 and $9,560 \mathrm{mg} \cdot \mathrm{kg}^{-1}$, respectively. Because the presence of organic matter in the sludge was comparatively low $\left(4.1 \mathrm{mg} \cdot \mathrm{kg}^{-1}\right)$, the risk of inhibition to culture growth can be ignored. The analysis showed that the sludge was enriched with heavy metals (42,180 and 20,160 $\mathrm{mg} \cdot \mathrm{kg}^{-1}$ for $\mathrm{Zn}$ and $\mathrm{Ni}$, respectively). These heavy metal contents are extremely high, posing a serious threat to the environment and human health. 


\section{Effect of Sludge Loading on Bio-Acidification During Bioleaching}

The effect of pulp density on $\mathrm{pH}$ during sludge bioleaching is shown in Fig. 2. In the absence of bacteria in control experiments, a marginal decrease in $\mathrm{pH}$ (3.02.63) was observed due to the chemical oxidation of elemental sulfur. Apparent $\mathrm{pH}$ reduction was observed while conducting bioleaching experiments. At the end of the bioleaching period $(480 \mathrm{~h})$, a decrease in $\mathrm{pH}$ value from 3 to $1.17,1.47,1.60,1.87$, and 2.03 was found for treatments with $1 \%, 2 \%, 3 \%, 4 \%$, and $5 \%$ SL. A decrease in $\mathrm{pH}$ value at $1 \% \mathrm{SL}$ was an indication of the good bacterial activity with respect to other SL treatments due to lower sludge toxicity [35]. From the dynamics of bio-acidification, it is clear that the decline in the rate of $\mathrm{pH}$ took place in the order of $1 \%>2 \%>3 \%>4 \%>5 \% \mathrm{SL}$. Therefore, it is concluded that bioleaching with different concentrations of electroplating sludge with similar initial $\mathrm{pH}$ shows a difference in bio-acidification due to heavy metal toxicity.

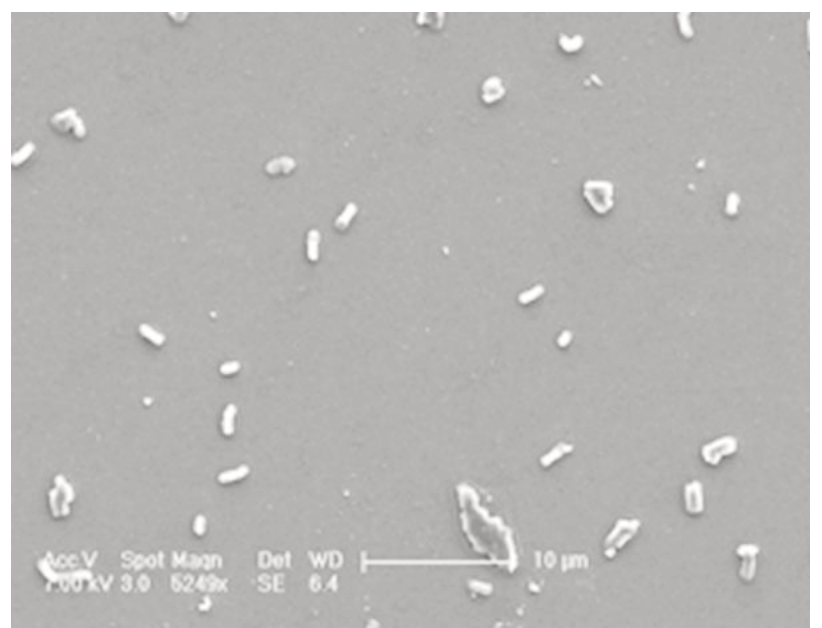

Fig. 1. SEM image of indigenous $A$. ferrooxidans.

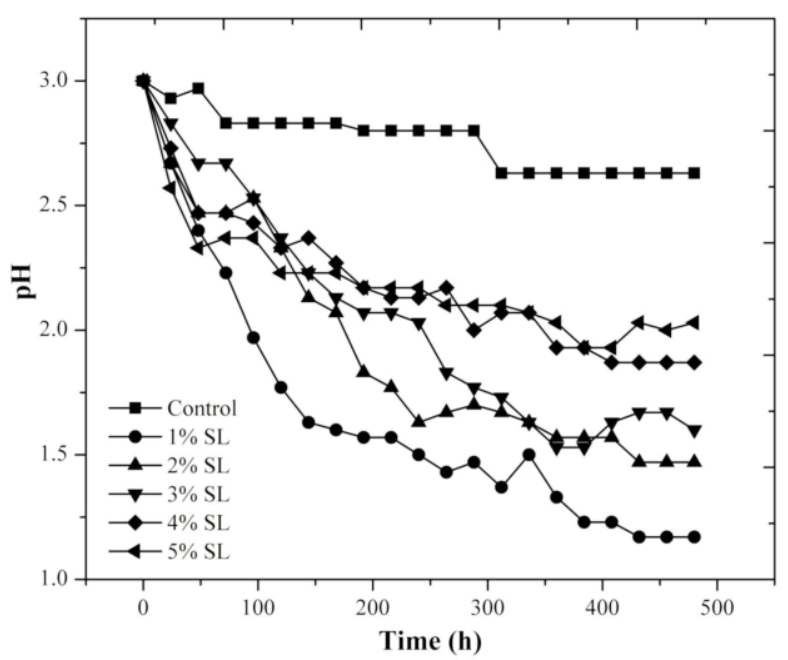

Fig. 2. $\mathrm{pH}$ variation in function of time for different sludge loadings during bioleaching.
Effect of Sludge Concentration on Oxidation-Reduction Potential during Bioleaching

The low $\mathrm{pH}$ value coupled with a high oxidizing environment is a favorable condition for an effective bioleaching process. In addition to bio-acidification, bio-oxidation of elemental sulfur contributes to an increase in ORP of the bioleaching medium. The increase in ORP can be attributed to the increase in the $\left[\mathrm{SO}_{4}{ }^{2-}\right]\left[\mathrm{H}^{+}\right] / \mathrm{O}_{2}$ ratio, which can occur by bacterial catalysis [36]. The variation in ORP during the bioleaching process is shown in Fig. 3. In the control experiment, the change in ORP was from 166 to $176.5 \mathrm{mV}$. Significant change in ORP of the bioleaching medium was observed in experiments with varying SLs (from $1 \%$ to $5 \%$ ). At the end of day 20, the flask with $1 \%$ SL showed considerable increase in ORP (from 173 to $630 \mathrm{mV}$ ). It was also observed that ORP increased from 185, 196, 218, and $199 \mathrm{mV}$ to $587,524,522$, and $483 \mathrm{mV}$ for the respective experiments with $2 \%, 3 \%, 4 \%$, and $5 \%$ SLs. The increase in ORP showed a similar trend as decreases in $\mathrm{pH}$ with respect to SL. The rate of ORP increase took place in the order of $1 \%>2 \%>3 \%>4 \%>5 \% \mathrm{SL}$, and it is well supported by the $\mathrm{pH}$ profiles.

\section{Effect of Sludge Loading on Heavy Metal Bioleaching}

Typical heavy metal bioleaching curves for $\mathrm{Zn}$ and $\mathrm{Ni}$ at different SLs are shown in Figs. 4 a) and b). From the experimental runs, it is evident that the bioleaching of heavy metals can be strongly influenced by SL. Bioleaching efficiency for $\mathrm{Zn}$ was the highest in all experiments with chosen SL because $\mathrm{Zn}$ can form into highly soluble $\mathrm{ZnSO}_{4}$ with sulfate. After 20 days of treatment, the bioleaching efficiencies of $\mathrm{Zn}$ were $96.31 \%, 94.46 \%$, $89.18 \%, 85.41 \%$, and $79.03 \%$ at the experiments with $1 \%$, $2 \%, 3 \%, 4 \%$, and $5 \%$ SL, respectively. The removal efficiencies of $\mathrm{Ni}$ were obtained as $84.40 \%, 80.47 \%, 75.81 \%$,

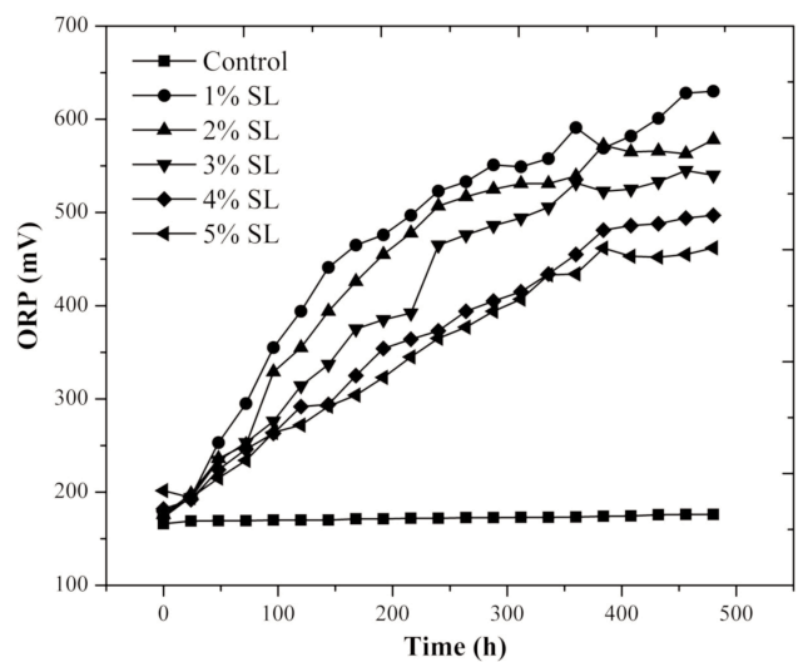

Fig. 3. ORP variation in function of time for different sludge loadings during bioleaching. 
a)

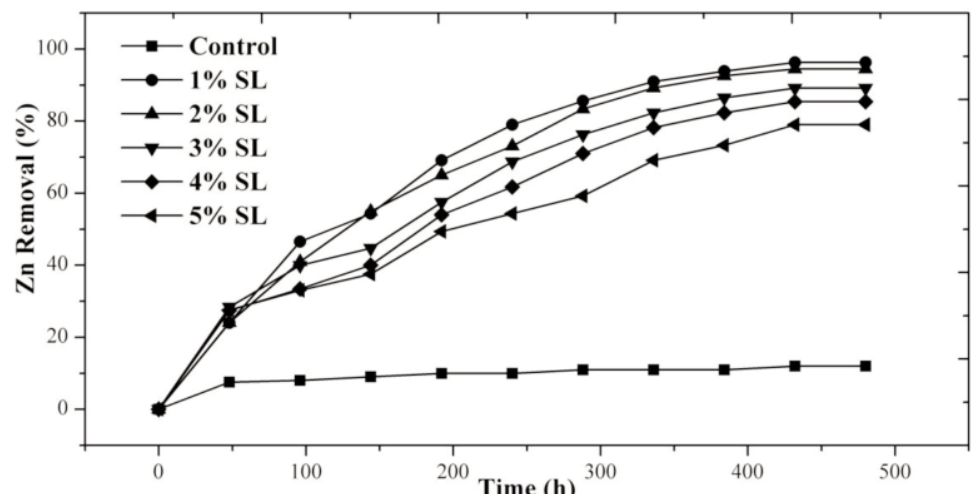

b)

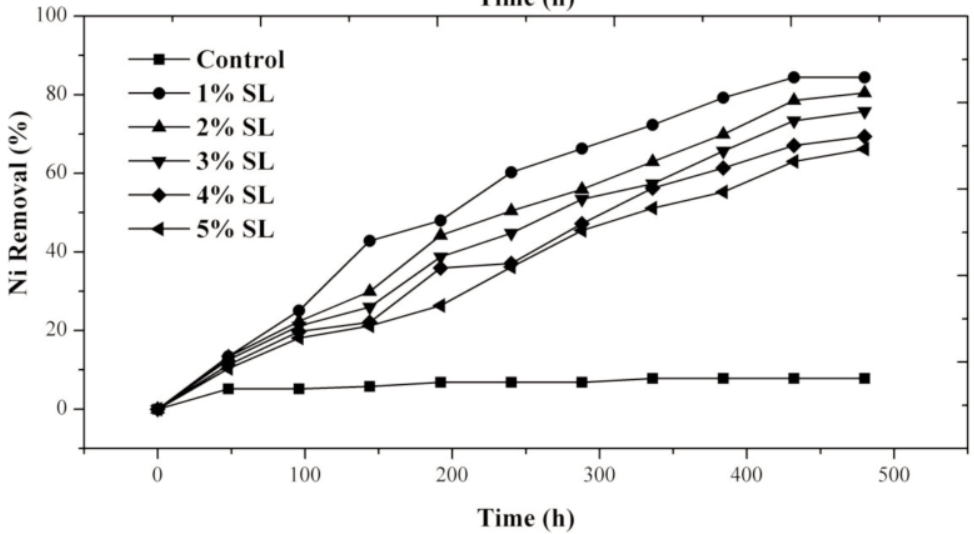

Fig. 4. a) Bioleaching of $\mathrm{Zn}$ in function of time for different sludge loadings. b) Bioleaching of Ni in function of time for different sludge loadings.

$69.38 \%$, and $66.14 \%$ at the experimental runs with $1 \%, 2 \%$, $3 \%, 4 \%$, and $5 \%$ of SL, respectively. The bioleached residue obtained from the experiment with 5\% SL was subjected to energy-dispersive X-ray spectroscopic (EDX) and Fourier transform infrared spectroscopic (FTIR) analyses. The spectra of EDX and FTIR analyses are given in Figs. 5 and 6. Results from the EDX analysis showed that elements $\mathrm{O}, \mathrm{Na}, \mathrm{Mg}, \mathrm{Al}, \mathrm{Si}, \mathrm{S}, \mathrm{K}, \mathrm{Ca}, \mathrm{Cr}, \mathrm{Ni}, \mathrm{Zn}$, and $\mathrm{Fe}$ were at weight percent of $52.62,1.85,0.85,6.88,24.96,0.47,1.05$, $10.47,0.09,0.05,0.65$, and 0.05 , respectively, and atomic percent of $68.97,1.68,0.74,5.34,16.23,0.31,0.56,5.48$, $0.04,0.02,0.21$, and 0.36 , respectively. This confirmed the reduction in heavy metal contents in treated sludge.

An interferogram of FTIR spectra (transmittance (T \%) plotted against the wavenumber $\left.\left(\mathrm{cm}^{-1}\right)\right)$ of bioleached sludge showed significant adsorption peaks at different wavenumbers, as shown in Fig. 6. This indicates the presence of different functional groups at leach residue resulting from reaction between chemicals used for media preparations and sludge components through bacterial catalysis. The broad adsorption band in the range of $600-700 \mathrm{~cm}^{-1}$ is assigned to Ni-O stretching vibration mode, which shows the broadness of adsorption band in the sludge. The broad adsorption band at $3,442 \mathrm{~cm}^{-1}$ is attributed to O-H stretching vibrations of coordinated water, and the weak band near $1,635 \mathrm{~cm}^{-1}$ is assigned to $\mathrm{H}-\mathrm{O}-\mathrm{H}$ bending vibrations [37]. These observations show the effect of hydration on structure and $\mathrm{OH}$ molecules present in the samples oxidized to form water molecules in order to reduce the intensity of hydroxides.
The removal efficiency of $\mathrm{Zn}$ from the sludge was higher than that of Ni. It has been reported that the bioleaching behavior of metals strongly depends on their chemical forms in the original sludge. The experimental data show that the removal efficiencies of heavy metal with respect to concentration of sludge took place in the order of $1 \%>2 \%$ $>3 \%>4 \%>5 \%$ SL, supporting the observations of Akcil et al. [38] and Bakhtiari et al. [39]. High SL causes higher shear stress, high toxicity, high mechanical damage to cells, and less oxygen mass transfer, which could result in reducing the bioleaching efficiency [40]. Therefore, the better

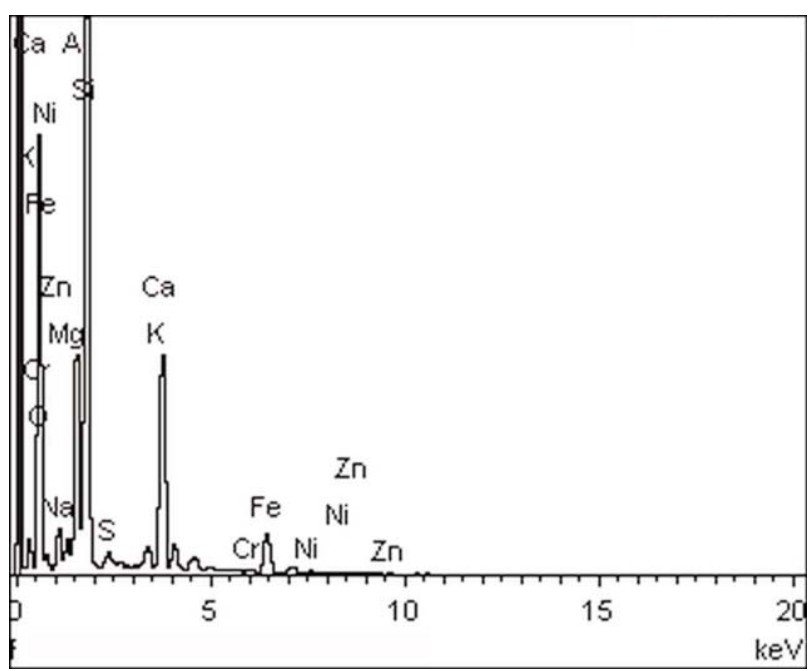

Fig. 5. EDX spectrum of bioleached residue. 


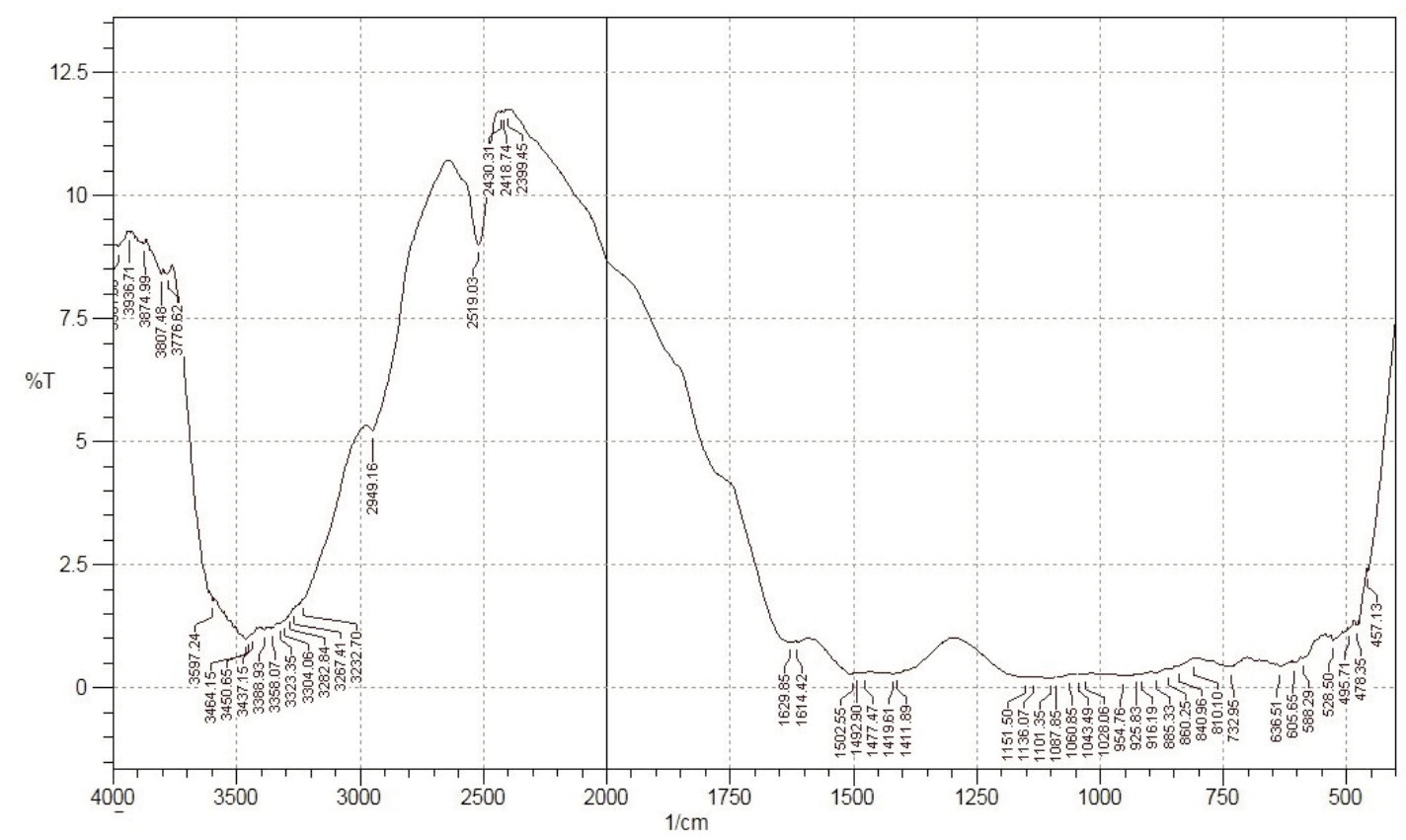

Fig. 6. FT-IR spectrum of bioleached residue.

a)

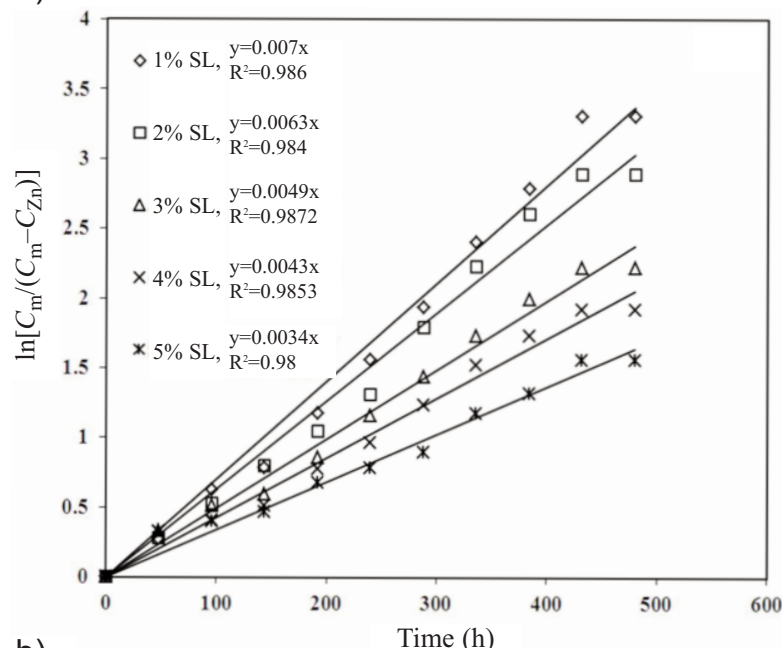

b)

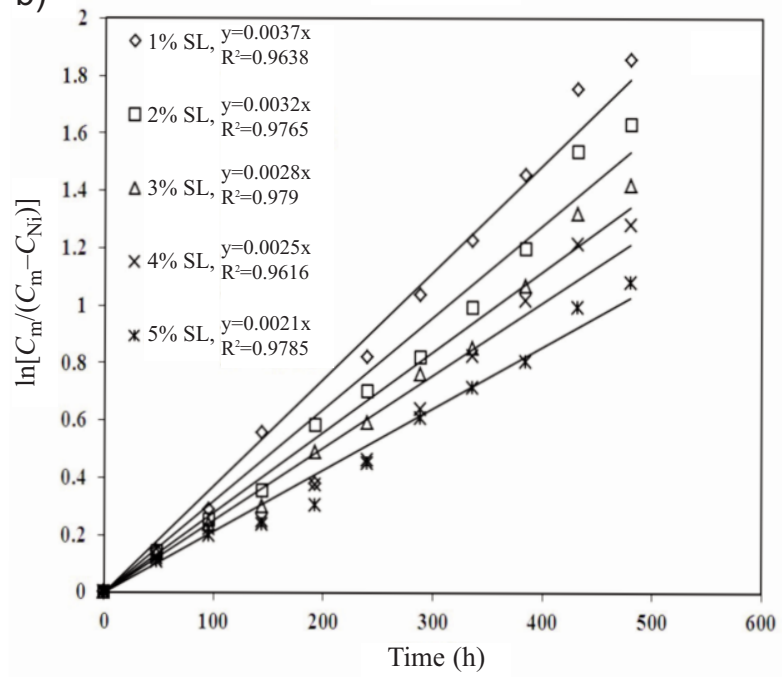

Fig. 7. a) Plot for kinetic rate constant of $\mathrm{Zn}$ bioleaching. b) Plot for kinetic rate constant of Ni bioleaching.
Table 3. Rate constant values and regression coefficients of $\mathrm{Zn}$ and $\mathrm{Ni}$ bioleaching.

\begin{tabular}{|c|c|c|c|c|}
\hline \multirow{2}{*}{$\begin{array}{c}\text { Sludge } \\
\text { composition }\end{array}$} & \multicolumn{2}{|c|}{$\mathrm{Zn}$} & \multicolumn{2}{c|}{$\mathrm{Ni}$} \\
\cline { 2 - 5 } & $k_{m}$-value & $\mathrm{R}^{2}$ & $k_{m}$-value & $\mathrm{R}^{2}$ \\
\hline $1 \% \mathrm{SL}$ & 0.007 & 0.986 & 0.0037 & 0.9638 \\
\hline $2 \% \mathrm{SL}$ & 0.0063 & 0.984 & 0.0032 & 0.9765 \\
\hline $3 \% \mathrm{SL}$ & 0.0049 & 0.9872 & 0.0028 & 0.979 \\
\hline $4 \% \mathrm{SL}$ & 0.0043 & 0.9853 & 0.0025 & 0.9616 \\
\hline $5 \% \mathrm{SL}$ & 0.0034 & 0.98 & 0.0021 & 0.9785 \\
\hline
\end{tabular}

heavy metal solubilization requires treatment, preferably with lower sludge concentration. However, further efforts should be made to improve the efficiency of bioleaching at a high concentration of sludge.

\section{Kinetic Study of Bioleaching}

Figs. 7 a) and b) show the fitting of the experimental results to Eq. (6) for $\mathrm{Zn}$ and $\mathrm{Ni}$. The values of rate constant $\left(k_{\mathrm{m}}\right)$ and corresponding correlation parameter $\left(\mathrm{R}^{2}\right)$ are summarized in Table 3 for the respective metals. The values of rate constant attained at experiments with $1 \%, 2 \%, 3 \%, 4 \%$, and $5 \%$ of SL were, respectively, $0.007,0.0063,0.0049$, 0.0043 , and $0.0034 \mathrm{~h}^{-1}$ for the removal of $\mathrm{Zn}$, and 0.0037 , $0.0032,0.0028,0.0025$, and $0.0021 \mathrm{~h}^{-1}$ for the removal of $\mathrm{Ni}$. It is evident that the concentration of sludge strongly affects the rate of metal bioleaching. Various rate-controlling steps of fluid-particle reaction kinetics, such as ash layer diffusion, chemical reaction, and diffusion through liquid film, were examined. Figs. 8 a) and b), 9 a) and b), 
Table 4. Regression coefficient values from the graphical fitting of different controlling step models.

\begin{tabular}{|c|c|c|c|c|c|c|}
\hline \multirow{2}{*}{ Sludge loadings } & \multicolumn{2}{|c|}{ Ash layer diffusion control } & \multicolumn{2}{c|}{ Chemical reaction control } & \multicolumn{2}{c|}{ Liquid film control } \\
\cline { 2 - 7 } & $\mathrm{Zn}$ & $\mathrm{Ni}$ & $\mathrm{Zn}$ & $\mathrm{Ni}$ & $\mathrm{Zn}$ & $\mathrm{Ni}$ \\
\hline $1 \% \mathrm{SL}$ & 0.967 & 0.930 & 0.979 & 0.991 & 0.7389 & 0.9193 \\
\hline $2 \% \mathrm{SL}$ & 0.957 & 0.770 & 0.977 & 0.956 & 0.7768 & 0.9859 \\
\hline $3 \% \mathrm{SL}$ & 0.957 & 0.819 & 0.967 & 0.975 & 0.788 & 0.9874 \\
\hline $4 \% \mathrm{SL}$ & 0.946 & 0.828 & 0.971 & 0.978 & 0.8358 & 0.9895 \\
\hline $5 \% \mathrm{SL}$ & 0.943 & 0.858 & 0.958 & 0.989 & 0.8221 & 0.9871 \\
\hline
\end{tabular}

and 10 a) and b) show the fitting of the experimental data to ash layer control, chemical reaction control, and liquid film control model for the metals $\mathrm{Zn}$ and Ni. Among the plots, the best fit was observed at the plot $\left[1-\left(1-X_{\mathrm{M}}\right)^{1 / 3}\right]$ $v s$ time. The kinetic data (Table 4) show a good fit to the chemical reaction-controlled SCM. The rate-controlling factor is a chemical reaction between sludge components and sulfuric acid.

a)
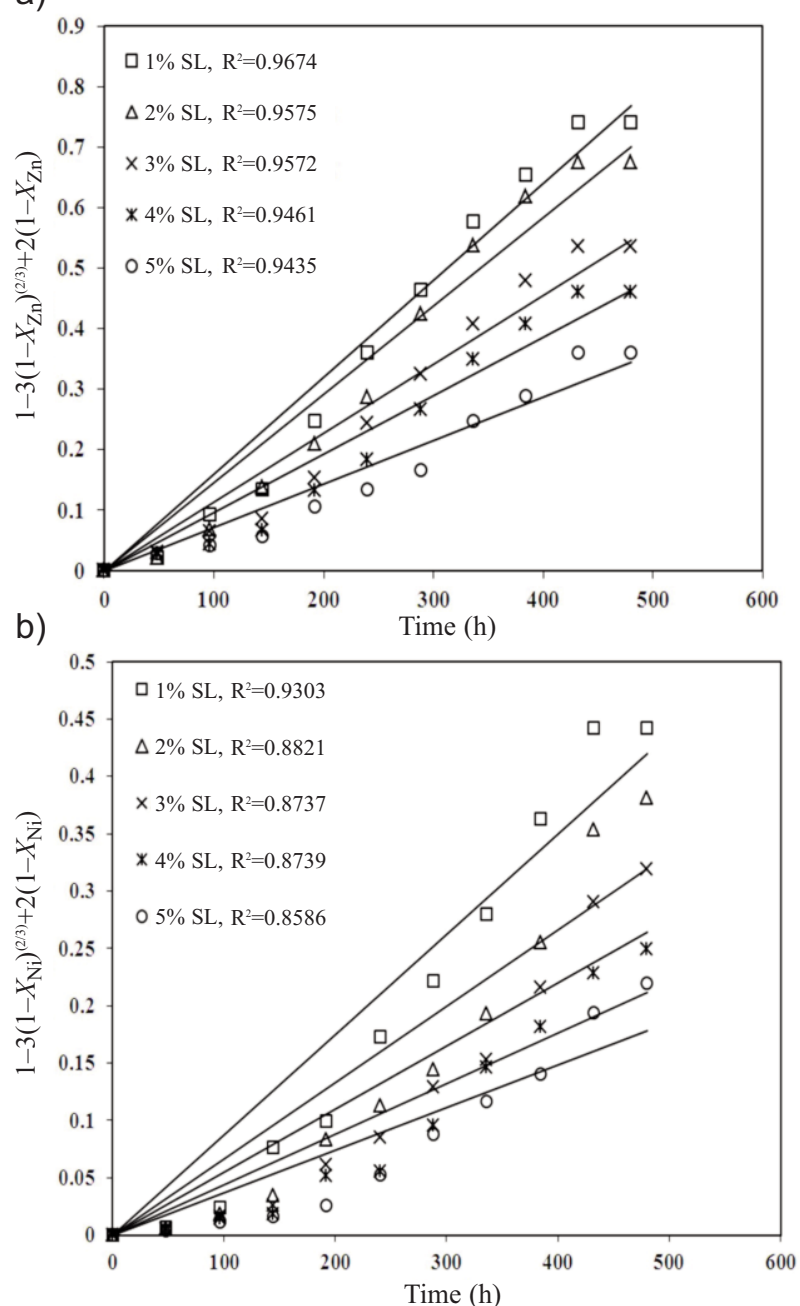

Fig. 8. a) Fitting of data to ash layer diffusion control model for $\mathrm{Zn}$ bioleaching. b) Fitting of data to ash layer diffusion control model for Ni bioleaching.

\section{Conclusions}

The removal efficiencies of $\mathrm{Zn}$ and $\mathrm{Ni}$ from the electroplating industrial sludge using the isolate $A$. ferrooxidans under the chosen experimental conditions were evaluated. The bioleaching data for different concentrations of sludge were observed. Owing to less toxicity, less shear stress, and
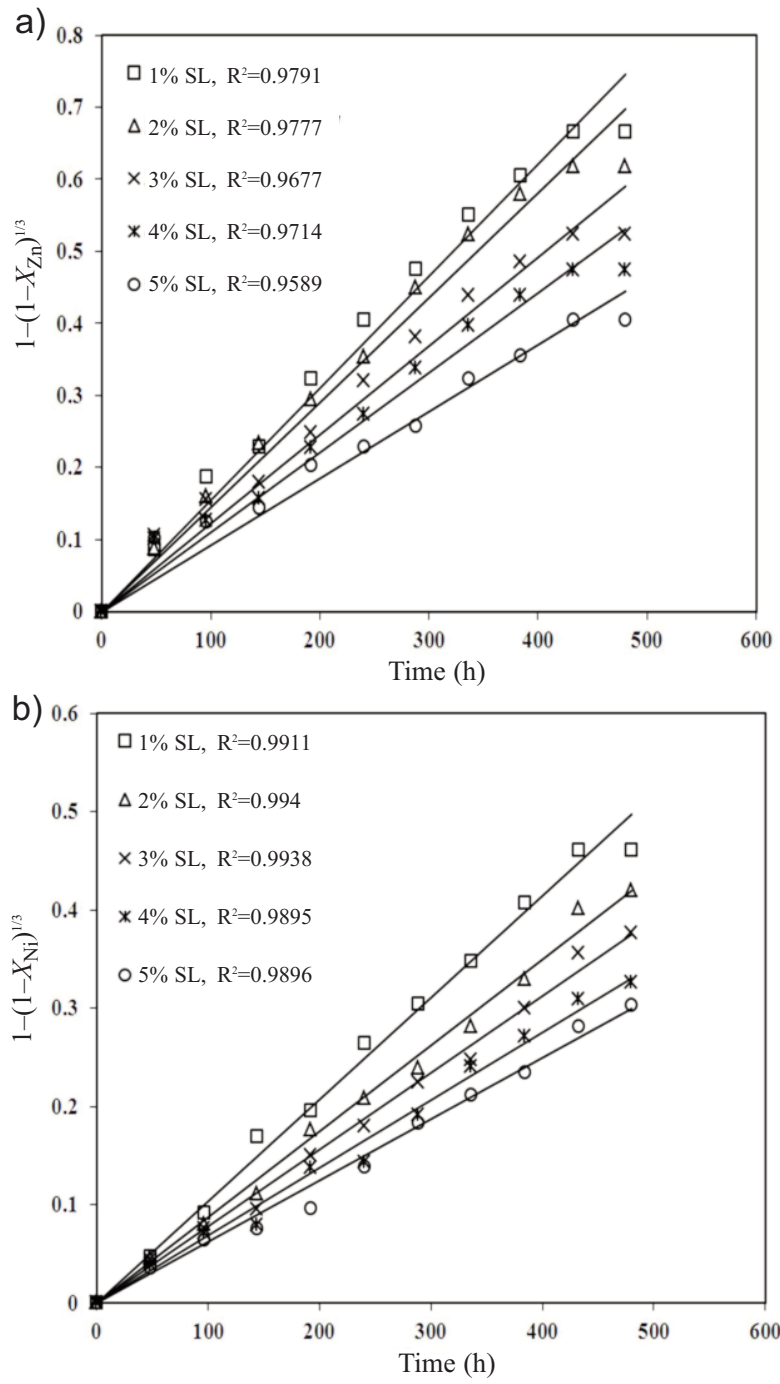

Fig. 9. a) Fitting of data to chemical reaction control model for bioleaching of $\mathrm{Zn}$. b) Fitting of data to chemical reaction control model in bioleaching of $\mathrm{Ni}$. 
a)

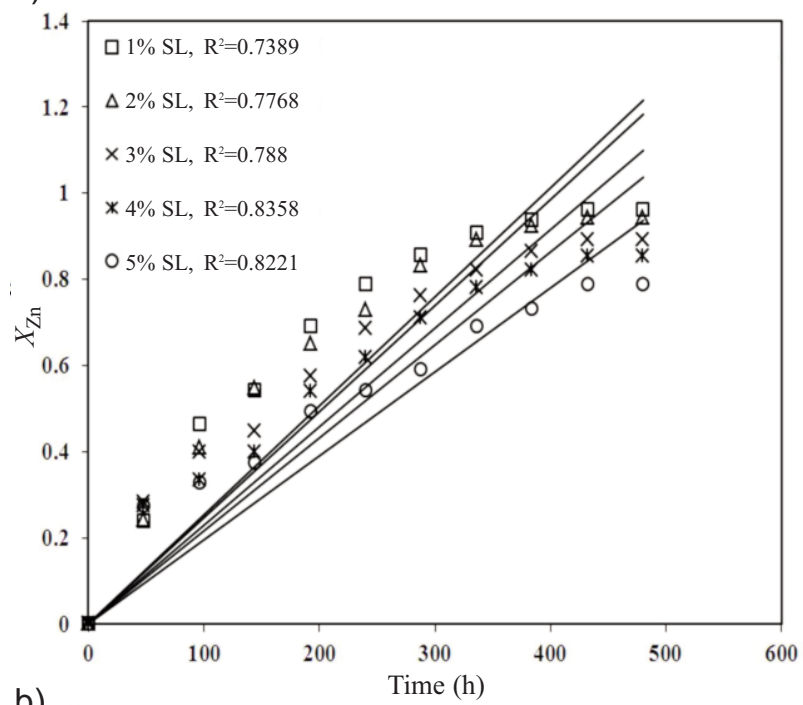

b)

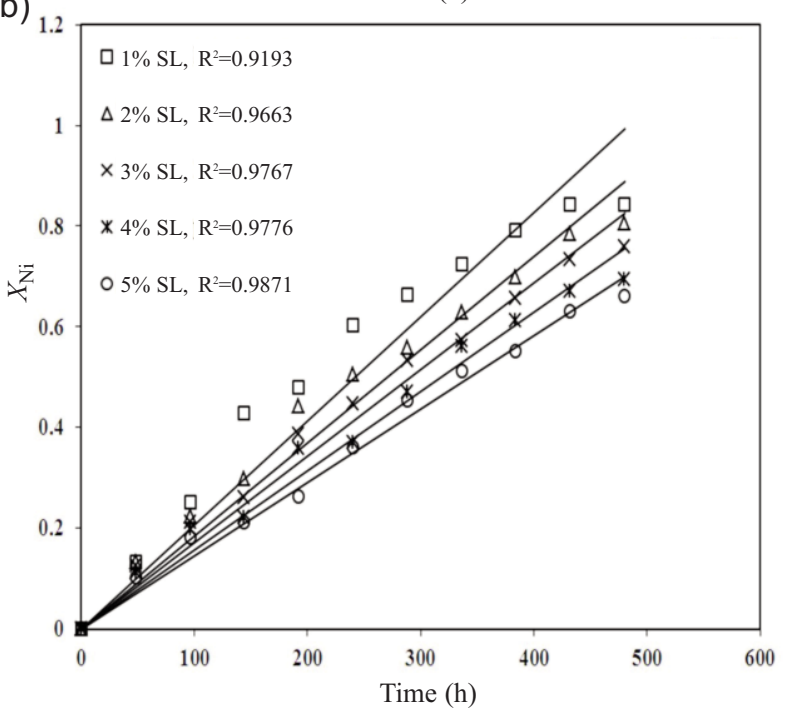

Fig. 10. a) Fitting of data to liquid film control model in bioleaching of $\mathrm{Zn}$. b) Fitting of data to liquid film control model in bioleaching of Ni.

better mass transfer effects, the lower sludge concentration becomes preferable for the effective bioleaching of heavy metals. Maximum removal efficiencies of $\mathrm{Zn}$ and $\mathrm{Ni}$ (96.31\% and $84.40 \%$, respectively) were achieved while using $1 \%(\mathrm{w} / \mathrm{v})$ SL. The bioleaching kinetics was studied for reaction rate constants of $\mathrm{Zn}$ and $\mathrm{Ni}$ removal from the sludge. It is apparent that the values of bioleaching rate constant were high at the treatment with $1 \%$ SL. On the basis of the SCM, the controlling step for the bioleaching reaction was identified as chemical reaction between sulfuric acid and sludge components. This study proved that it is feasible to detoxify the electroplating sludge containing heavy metals using the bioleaching process.

\section{References}

1. REHMAN A. U., LEE S. H. Review of the Potential of the $\mathrm{Ni} / \mathrm{Cu}$ Plating Technique for Crystalline Silicon Solar Cells, Materials. 7, 1318, 2014.
2. ADAMCZYK-SZABELA D. Assessing Heavy metal Content in Soils Surrounding Electroplating Plants. Pol. J. Environ. Stud. 22, 1247, 2013.

3. HUANG R., HUANG K.-L., LIN Z.-Y., WANG J.-W., LIN C., KUO Y.-M. Recovery of valuable metals from electroplating sludge with reducing additives via vitrification. J. Environ. Manage. 129, 586, 2013

4. SOCHACKI A., SURMACZ-GÓRSKA J., FAURE O., GUY B. Polishing of synthetic electroplating wastewater in microcosm upflow constructed wetlands: Metals removal mechanisms. Chem. Eng. J. 242, 43, 2014.

5. DHAL. B., THATOI. H.N., DAS. N.N., PANDEY. B.D., chemical and microbial remediation of hexavalent chromium from contaminated soil and mining/metallurgical solid waste: A review. J. Hazard. Mater. 250, 272, 2013.

6. WANG Y.-S., PAN Z.-Y., JIAN-MIN., XU J.-M., ZHENG Y.-G. Bioleaching of Chromium from tannery sludge by indigenous Acidithiobacillus thiooxidans. J. Hazard. Mater. 147, 319, 2007.

7. SABRA N., DUHOURGUIER H. C., DUVAL M.-N., HAMIEH T. Study of canal sediments contaminated with heavy metals: fungal versus bacterial bioleaching techniques. Environ. Technol. 32, 1307, 2011.

8. LUCZKIEWICZ. A., QUANT. B. Soil and Groundwater Fecal Contamination as a Result of Sewage Sludge Land Application. Pol. J. Environ. Stud. 16, 587, 2007.

9. RADMILA. N. PIVIC., ALEKSANDRA B. STANOJKOVI SEBIC., DRAGANA LJ. JOSIC. Assessment of Soil and Plant Contamination by Select Heavy Metals Along a major European Highway. Pol. J. Environ. Stud. 22, 1465, 2013.

10. IRSHAD M., MALIK A. H., SHAUKAT S., MUSHTAQ S., ASHRAF M. Characterization of Heavy Metals in Livestock Manures. Pol. J. Environ. Stud. 22, 1257, 2013.

11. COUILLARD D., CHARTIER M., MERCIER G. Bacterial Leaching of Heavy Metals from Aerobic Sludge. Bioresource. Technol. 36, 293, 1991.

12. BABEL S., DEL MUNDO DACERA D. Heavy metal removal from contaminated sludge for land application: A review. Waste. Manage. 26, 988, 2006.

13. ZENG G., LUO S., DENG X., LI L., AU C. Influence of silver ions on bioleaching of cobalt from spent lithium batteries. Miner. Eng. 49, 40, 2013.

14. BOSECKER K. Bioleaching: metal solubilization by microorganisms, FEMS. Microbial. Rev. 20, 591, 1997.

15. IRAM S., ZAMAN A., IQBAL Z., SHABBIR R. Heavy Metal Tolerance of fungus Isolated from Soil contaminated with Sewage and Industrial Wastewater. Pol. J. Environ. Stud. 22, 691, 2013.

16. DAS T., AYYAPPAN S., CHAUDHURY G. R. Factor affecting bioleaching kinetics of sulfide ores using acidophilic-organisms. Biometals. 12, 1, 1999.

17. JAIN N., SHARMA D.K. Biohydrometallurgy for Nonsulfidic Minerals-Review. Geomicrobiol. J. 21, 135, 2004.

18. ABDOLLAHI H., SHAFAEI S.Z., NOAPARAST M., MANAFI Z., ASLAN N. Bio-dissolution of $\mathrm{Cu}$, Mo and Re from molybdenite concentrate using mix mesophilic microorganism in shake flask, Trans. Nonferrous. Met. Soc. China. 23, 219, 2013.

19. NOWACZYK K., DOMKA F. Oxidation of Pyrite and Marcasite by Thiobacillus ferrooxidans bacteria. Pol. J. Environ. Stud. 9, 87, 2000.

20. QIU M.-Q., XIONG S.-Y., ZHANG W.-M., WANG G.-X. A comparison of bioleaching of chalcopyrite using pure culture or a mixed culture. Miner. Eng. 18, 987, 2005. 
21. ZHU Y., ZENG G., ZHANG P., ZHANG C., REN M., ZHANG J., CHEN M. Feasibility of bioleaching combined with Fenton-like reaction to remove heavy metals from sewage sludge. Bioresource Technol. 142, 530, 2013.

22. PARK D., LEE D. S., PARK J. M., CHUN H. D., KOOK S., JITSUHARA I., MIKI O., KATO T. Metal Recovery from Electroplating Wastewater Using Acidophilic Iron Oxidizing Bacteria: Pilot-Scale Feasibility Test. Ind. Eng. Chem. Res. 44, 1854, 2005.

23. FANG D., ZHAO L., ZHOU L.X., SHAN H.X. Effect of sulfur on heavy metal bioleaching from contaminated sediments. J. Environ. Sci. Heal. A. 44, 714, 2009.

24. NOWACZYK K., JUSZCZAK A., DOMKA F., SIEPAK. J. The use of Thiobacillus ferrooxidans bacteria in the Process of Chalcopyrite Leaching. Pol. J. Environ. Stud. 7, 307, 1998.

25. NOWACZYK K., DOMKA F. Kinetic Model of CuS Oxidation by Thiobacillus ferrooxidans and Thiobacillus thiooxidans Bacteria. Pol. J. Environ. Stud. 9, 195, 2000.

26. YANG Y., CHEM S., LI S., CHEN M., CHEN H., LIU B. Bioleaching waste printed circuited boards by Acidithiobacillus ferrooxidans and its kinetics aspect. J. Biotechnol. 173, 24, 2014.

27. APHA. Standard Methods for the Examination of Water and Wastewater, 20 ${ }^{\text {th }}$ edition, American Public Health Association. Washington, DC, 1995.

28. NARESH KUMAR R., NAGENDRAN R. Changes in nutrient profile of soil subjected to bioleaching for removal of heavy metals using Acidithiobacillus thiooxidans. J. Hazard. Mater. 156, 102, 2008.

29. TRIVEDY R.K., GOEL P.K., TRISAL C.L. Practical Methods in Ecology and Environmental Science, Environmental Publications. Karad, India, 1987.

30. KONISHI Y., MATSUI M., FUJIWARA H., NOMURA T., NAKAHARA K. Zinc Leaching from Fly Ash in Municipal Waste Incineration by Thermophilic Archaean Acidianus brierleyi growing on Elemental Sulphur. Separ. Sci. Technol. 38, 4117, 2003.
31. WATLING H.R., WATKIN E.L.J., RALPH D.E. The resilience and versatility of acidophiles that contribute to the bio-assisted extraction of metals from mineral sulphides, Environ. Technol. 32, (8), 915, 2010.

32. CHEN S. -Y., LIN J.-G. Effect of substrate concentration on bioleaching of metal-contaminated sediment. J. Hazard. Mater. 82, 77, 2001.

33. LIAO M.X., DENG T.L. Zinc and lead extraction from complex raw sulfides by sequential bioleaching and acid brine leach. Miner. Eng. 17, 17, 2004.

34. BAKHTIARI F., ATASHI H., ZIVDAR M., SEYEDBAGHERI S., FAZAELIPOOR M. H. Bioleaching kinetics of copper from copper smelters dust. J. Ind. Eng. Chem. 17, 29, 2011

35. KODALI B., BHAGVANTH RAO M., LAKSHMI NARASU M., POGAKU R. Effect of biochemical reaction in enhancement of rate of leaching. Chem. Eng. Sci. 59, 5069, 2004.

36. PATHAK A., DASTIDAR M.G., SREEKRISHNAN T.R. Bioleaching of heavy metals from anaerobically digested sewage. J. Environ. Sci. Heal. A. 43, 402, 2008.

37. THEO KLOPROGGE J, LEISEL HICKEY., RAY L. FROST. FT-Raman and FT-IR spectroscopic study of synthetic $\mathrm{Mg} / \mathrm{Zn} / \mathrm{Al}$-hydrotalcites. J. Raman. Spectrosc. 35, 967, 2004.

38. FANG D., JIN C.J., ZHOU L.X. Removal of Cr from tannery sludge by indigenous sulfur-oxidizing bacteria. J. Environ. Sci. Heal. A. 42, 2065, 2007.

39. AKCIL A., CIFTCI H., DEVECI H. Role and contribution of pure and mixed culture of mesophiles in bioleaching of a pyritic chalcopyrite concentrate. Miner. Eng. 20, 310-318, 2007.

40. BAKHTIARI F., ATASHI H., ZIVADAR M., SEYEDBAGHERI S., FAZAELIPOOR M. H. Bioleaching kinetics of copper from copper smelter dust. J. Ind. Eng. Chem. 17, 29, 2011. 
